\title{
Tectonics-mineralisation relationships within weak continental lithospheres: a new structural framework for Precambrian cratons
}

\author{
Denis Gapais* \\ Géosciences Rennes, UMR CNRS 6118, Université de Rennes 1, 35042 Rennes cedex, France
}

Received: 22 March 2018 / Accepted: 24 August 2018

\begin{abstract}
Many Archaean and Paleoproterozoic cratons show deformation patterns that differ from those observed in modern orogens. On the other hand, they constitute an important part of present-day emerged continents and contain a large part of continental mineral resources known to date. On the basis of a summary of structural data from some typical field examples and of results of analogue modelling, we emphasize that pop-down tectonics marked by vertical burial of supracrustals within an underlying hot and weak crust may be the most suitable model to account for deformation patterns of many ancient deformation zones. An overview of relationships between structural patterns and mineralisation in several ancient deformation zones further emphasizes that pop-down tectonics provides a very promising structural framework for mining exploration in Precambrian cratons.
\end{abstract}

Keywords: tectonics / Precambrian / weak lithospheres / crustal shortening / mineralisation

\begin{abstract}
Résumé - Relations tectonique-minéralisation dans les lithosphères continentales chaudes, applications aux cratons précambriens. De nombreux cratons Archéens et Paléoprotérozoïques montrent des champs de déformations qui diffèrent de ceux typiques des zones orogéniques modernes. Parallèlement, ces cratons constituent une part importante des domaines continentaux actuels et contiennent une grande part des ressources minérales qui y sont connues à ce jour. Une synthèse des données structurales sur quelques exemples de terrain représentatifs et de résultats de modélisations analogiques montre qu'une tectonique verticale marquée par l'enfouissement de dépôts de croûte supérieure dans une croûte sousjacente chaude et molle est le meilleur modèle qui rende compte des structures caractéristiques de beaucoup de zones de déformation précambriennes. Un aperçu des relations entre structures et minéralisationshowing main mineral deposits on contine dans plusieurs zones de déformation montre en outre que ce modèle fournit un cadre structural très prometteur pour l'exploration minière dans les cratons anciens.
\end{abstract}

Mots clés : tectonique / précambrien / lithosphères molles / raccourcissement crustal / minéralisation

\section{Introduction}

\subsection{Deformation modes of ancient hot lithospheres: an academic challenge}

Deformation modes of ancient cratons, especially those of Archaean age, are subject of disputed debates since several decades (see Windley, 1992, 1995). Before the remarkable advent of plate tectonics in the late sixties (McKenzie and Parker, 1967; Le Pichon, 1968; Morgan, 1968; Dewey and Bird, 1970), many works emphasized the importance of vertical deformations involving the rising of hot and light partially melted lower granitic crust following models of diapirism (Eskola, 1949; Ramberg, 1963, 1967; Brun et al., 1981). Since the emergence of plate tectonics, two main "schools" have developed: those of

*Corresponding author: denis.gapais@univ-rennes1.fr uniformitarism type based on modern plate tectonics with attached stiff plates and continental deformations localized at plate boundaries following classical thrusting models, as argued for the Alps or the Himalayas (Fig. 1a); and those that emphasized the hotter and weaker rheological state of continental crusts during early periods of crustal growth (Fig. 1b and c) (see Windley, 1995 and refs. therein). Classical models evoking weak lithospheres during Archaean times involve combined diapirism of the lower crust (Dixon, 1975, Schwerdtner et al., 1979) and gravity-driven sinking, sagduction, of heavy greenstone-bearing upper crust within the underlying partially melted crust (Choukroune et al., 1995; Chardon et al., 1998; Collins and Van Kranendonk, 1998; Lin and Beakhouse, 2013) (Fig. 1b). According to these models, one should expect a threshold in late Archaean times between greenstone-driven gravity deformation models and greenstone-lacking deformations. On the other hand, since the early 2000th, field works and 
Convergence tectonics between stiff plates crustal-scale thrusts

and exhumation of high pressure rocks along detachments

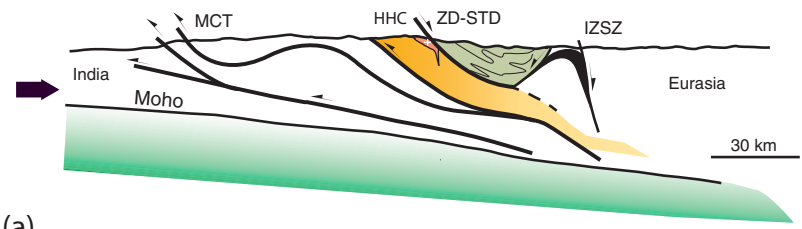

(a)

Gravity-driven deformations vertical motions involving sagduction of heavy greenstones and rising of light underlying partially melted crust

(b)

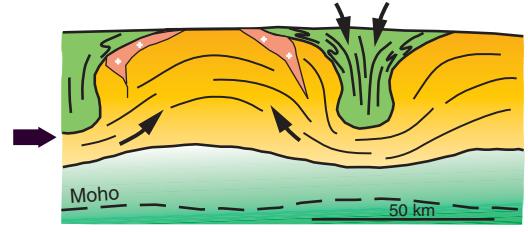

Convergence tectonics of hot and buoyant lithosphere horizontal longitudinal flow combined with vertical tectonics and burial

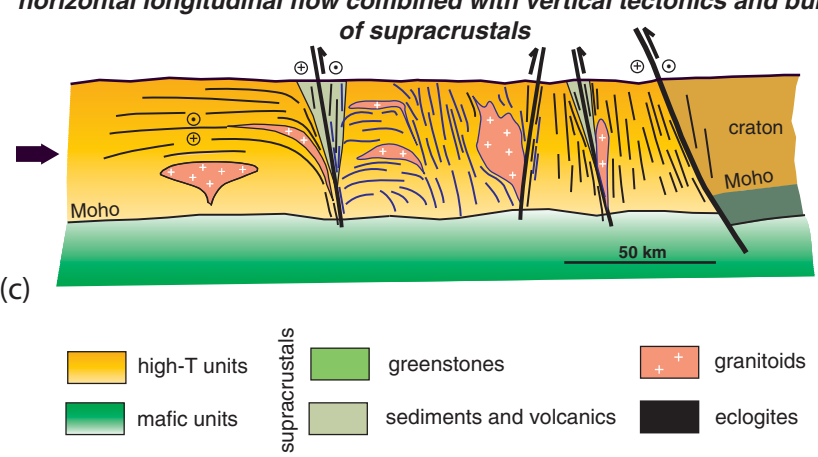

Fig. 1. Synthetic schematic cross-sections illustrating the three main modes of deformation of convergent continental lithospheres. (a) Modern-type tectonics involving stiff lithospheres where compression induces localised strains with crustal-scale thrusts and extensional detachments. The section makes particular reference to the India-Eurasia collision belt (from Gapais et al., 1992, 2009 and Indepth profile, Nelson et al., 1996). MCT, Main Central Thrust; ZD-STD, Zanskar Detachment and South-TibetDetachment; IZSZ, Indus-Zangbo Suture Zone; HHC, High Himalayan Crystalline. Combined thrusting and normal shearing leads to the exhumation of the Higher Himalaya Crystalline (Gapais et al., 1992). Exhumation of eclogites, such as the Tso Morari eclogites (western Himalaya), is associated with crustal scale normal shearing (De Sigoyer et al., 2000, 2004). (b) General pattern of gravity-driven deformation models for Archaean tectonics, that generally involve combined rising of hot and partially melted crust (diapirism) and sinking of heavy mafic greenstone belts (sagduction). Drawing after Collins and Van Kranendonk (1998), and Chardon et al. (1998). (c) General tectonic model combining thickening and horizontal flow of a hot continental lithosphere in a compressive setting, with burial of light supracrustals within soft crust along vertical deformation zones (from Gapais et al., 2005, Gapais et al., 2008, 2009; Chardon et al., 2009). See text for further explanations. analogue models have emphasized that vertical tectonics did not necessarily require gravity-driven sagduction processes, but just implied a hot and weak lithosphere, with a ductile lithospheric mantle, allowing burial of light upper crustal rocks during compression (Cagnard et al., 2006a; Chardon et al., 2009). Consistently, similar deformation patterns are observed within Archaean greenstone belts and Paleoproterozoic belts (Gapais et al., 2005; Chardon et al., 2009, Gapais et al., 2009 and refs. therein) (Fig. 1c). According to available experimental data, the thermal threshold between a localizing and a ductile lithospheric mantle corresponds to a Moho temperature around $800^{\circ} \mathrm{C}$ (Ranalli, 1997, Sandiford and McLaren, 2002; Précigout et al., 2007).

Although many new evidence showing the importance of syn-shortening vertical kinematics in ancient deformation belts have been recently published (see Rey and Houseman, 2006; Chardon et al., 2009; Gapais et al., 2009; Bédard, 2018), discussions on the subject are still a matter of international debates, with ongoing models of thrust tectonics and postthickening extensional extension (e.g., Block et al., 2013, 2015 ) or of gravity-driven vertical motions (e.g., Lin and Beakhouse, 2013).

\subsection{Deformation modes of ancient hot lithospheres: an economic challenge}

Beside the academic challenge, the debate on deformation modes of ancient cratons is crucial with respect to mining exploration purposes. Indeed, a large amount of continental mineral resources known to date are concentrated within Archaean and Paleoproterozoic belts that represent a substantial part of emerged continents (Fig. 2). Robust tectonic models are therefore a first order basis to develop constructive projects for mining exploration in these regions.

\section{Shortening modes of weak lithospheres: what do field examples tell us}

\subsection{Upper crust}

Prominent structures within the low metamorphic grade upper crust are basically sub-vertical (see Gapais et al., 2009; Chardon et al., 2009). Main features are steep cleavages bearing widespread steeply plunging stretching lineations. Field examples illustrated here are from Paleoproterozoic rocks from the gold-bearing Trans-Amazonian belt in Suriname (Fig. 3a), Archaean rocks from the antimony-bearing Murchison Belt in South Africa (Fig. 3b), and Archaean rocks from the gold-bearing Southern Abitibi Belt in Canada (Fig. 3c).

\subsection{Middle and lower partially melted crust}

Most Archaean cratons and Paleoproterozoic belts show widespread outcrops of the mid-crust, with HT-MP peak metamorphic conditions, often partially melted and (or) under granulite facies (e.g., Reindeer zone and Kisseynew domains, 


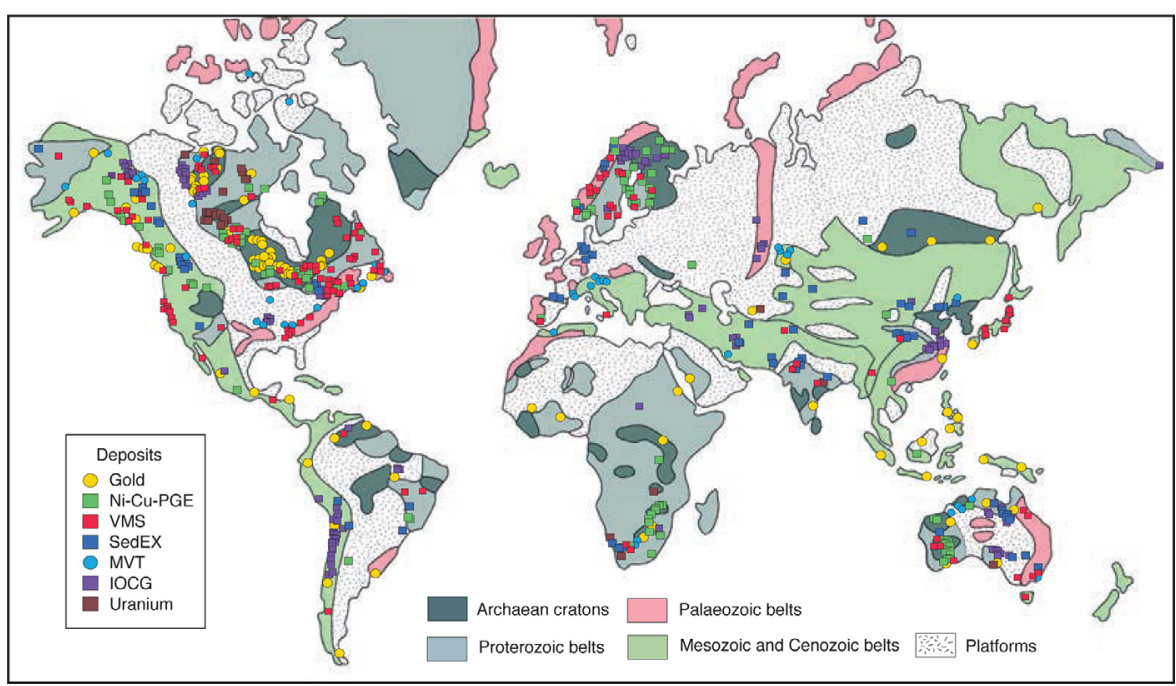

Fig. 2. World map showing main mineral deposits on continents. Porphyry and oceanic deposits are not shown. The map emphasizes that Archaean and Paleoproterozoic belts are particularly rich in mineralisation. VMS, Volcanic Massive Sulfides; MVT, Mississippi Valley Type, IOGC, Iron Oxide, Gold, Copper mineralisation. Data compilation from Canadian Natural Resources, Goodfellow (2007).
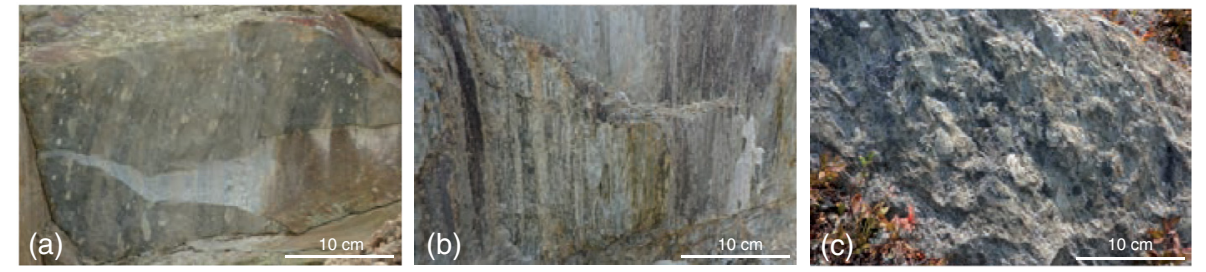

Fig. 3. Examples of upper-crustal structures. (a) Steeply plunging stretching lineation underlined by stretched pebbles on a steeply dipping cleavage within weakly metamorphosed conglomerates (Paleoproterozoic, Rosebel area, Transamazonian Belt, Suriname). (b) Vertical mylonitic fabric bearing vertical stretching lineation within the "Murchison schists" (Archaean, greenschist facies, Murchison Greenstone Belt, South Africa) (modified after Jaguin et al., 2012). (c) Steeply plunging stretching lineation underlined by stretched pebbles in conglomerates (Archaean, southern Abitibi Province, Quebec, Canada).

Canada; Thompson Nickel Belt, Canada; Terre Adélie, Antarctica; Svecofennides, Finland; Dharwar Craton, India) (see Gapais et al., 2009 and refs. therein).

Finnish Svecofennides is a remarkable example for both, structures and metamorphic conditions (Fig. 4a). In southern Finland, the Svecofennides crop out on about $125000 \mathrm{~km}^{2}$. The regional trend of the belt is NE-SW and metamorphic conditions are extremely monotonous, with PT conditions around $750{ }^{\circ} \mathrm{C}$ and $400-500 \mathrm{MPa}$ (see Väisänen and Hölltä, 1999; Cagnard et al., 2007) (Fig. 4a). The overall regional structural pattern is that of regionally shortened domes and basins, mainly made of granitoids and of migmatitic supracrustals, respectively (Cagnard et al., 2007). Two types of structures are observed: steeply dipping large strain zones marked by mylonitic fabrics bearing steeply plunging stretching lineations (Fig. 4b), and domains of flat-lying foliations (Fig. 4c). Stretching lineations are typically scattered along a NE-SW strike, with steeply plunging lineations on steeply dipping foliations and along-strike gently plunging lineations on gently dipping foliations (Fig. 4a).

Similar structural patterns combining domains of gently dipping fabrics with along strike stretching lineations and steeply dipping fabrics with steeply plunging lineations have been reported for other areas, of both Archaean age (e.g., Dharwar craton; Chardon et al., 2009) and Paleoproterozoic age (e.g., Thompson Nickel Belt or Terre Adélie; Gapais et al., 2005, 2008). Many lines of evidence indicate that their development was partly coeval, under HT-MP metamorphic conditions (see Chardon et al., 2009). This is illustrated in Figure 5 that shows garnet-bearing leucosomes associated with both flat-lying and steeply dipping fabrics in the Finnish Svecofennides (Fig. 5a and b), and vertical melt bearing deformation bands in Terre Adélie cutting across flat lying migmatitic layering (Fig. 5c) and vice versa (Fig. 5d) (Gapais et al., 2008). In the example of the Terre Adélie, the combined development of the two types of structures is further supported by rather homogeneous peak metamorphic conditions (Pelletier et al., 2005) and by sharply well bracketed U-Pb ages of the partial melting event at around $1.7 \mathrm{Ga}$ (Peucat et al., 1999).

\subsection{Interpretation}

What may first be inferred from field data is the predominance of vertical motions compared to horizontal ones (Cagnard et al., 2006a; Chardon et al., 2009; Gapais et al., 2009). The occurrence of flat-lying foliated domains marked by belt-parallel stretching has been interpreted as reflecting horizontal belt-parallel flow of a weak and partially melted middle and lower continental crust. A general kinematic model 


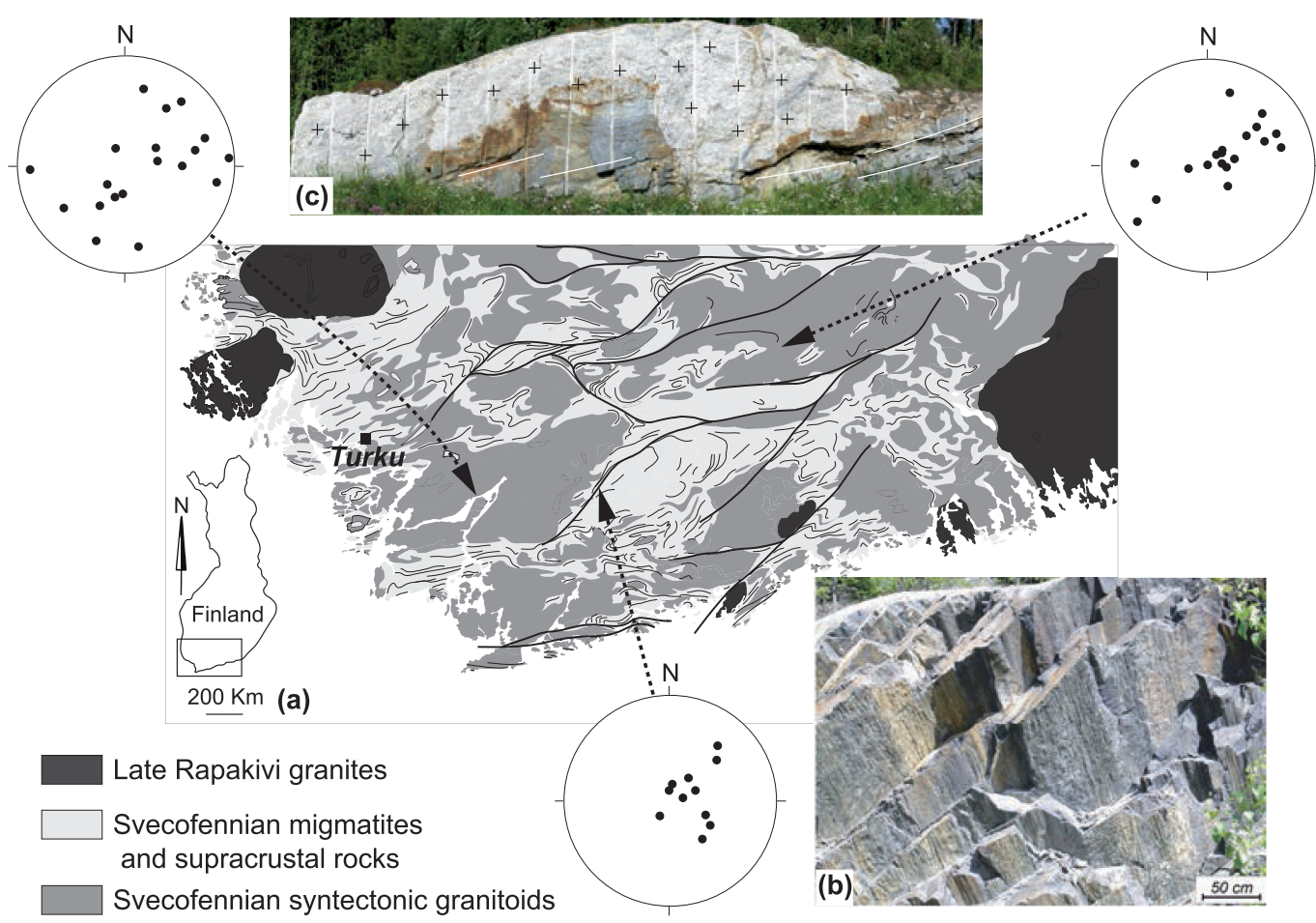

Fig. 4. Examples of lower crustal structures, Paleoproterozoic Finnish Svecofennides. (a) Schematic geological map showing traces of metamorphic foliations and some main shear zones (after Korsman et al., 1997). The regional pattern underlines bulk NNW-SSE shortening. Stereograms (lower hemisphere, equal angle) show examples of attitudes of the stretching lineations. These are subvertical within major shear zones and are scattered along belt strike outside them. NE-SW striking gently plunging lineations correspond to domains of gently dipping foliations. (b) Example of steeply dipping foliation bearing a steeply plunging lineation. (c) Example of domain of flat-lying fabric, with a small laccolith-type granitic intrusion (crosses) within flat-lying foliation. Modified after Cagnard et al., $2006 \mathrm{a}$.
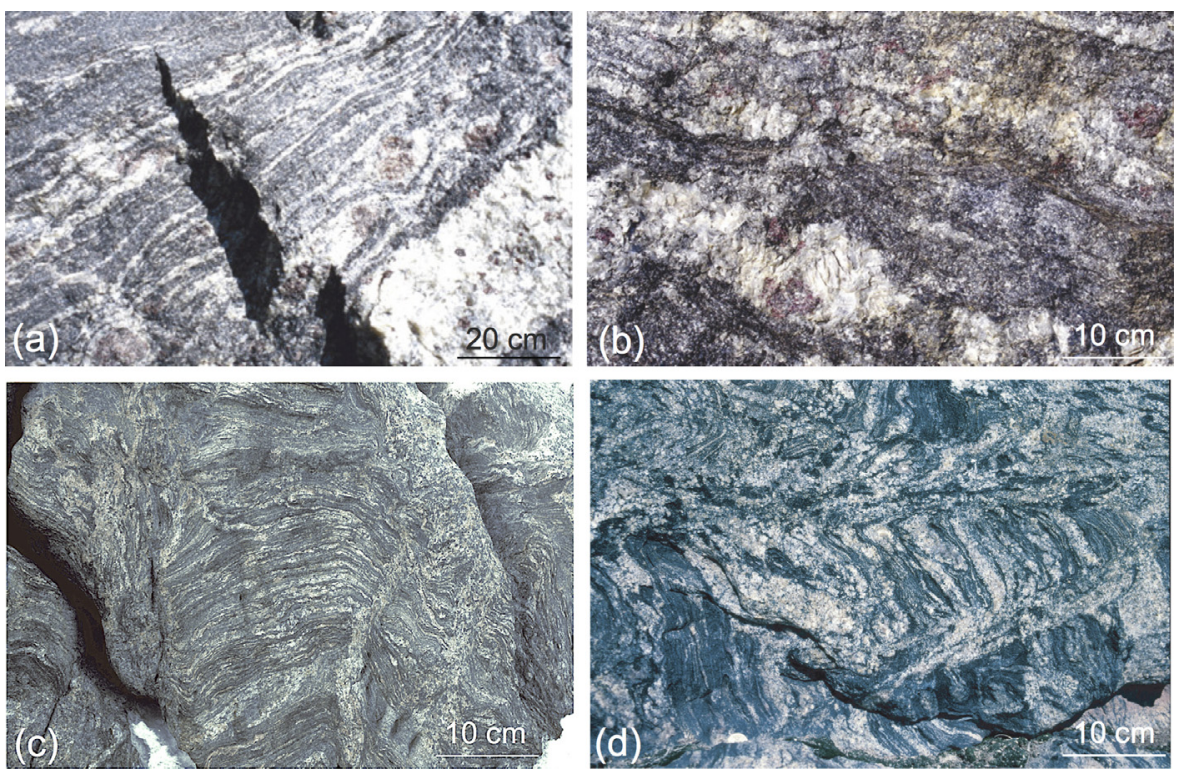

Fig. 5. Examples of field relationships between domains of steeply dipping and gently dipping fabrics. (a, b) subvertical (a) and flat-lying (b) migmatitic fabrics underlined by garnet-bearing leucosomes (Finnish Svecofennides). (c, d) migmatites from Terre Adélie showing steeply dipping leucosomes cross-cutting gently dipping foliation (c) and gently dipping leucosomes cross-cutting steeply dipping foliation (d).

was first proposed by Gapais et al. (2005) for tectonics in the Thompson Nickel Belt (Manitoba) and then applied to other areas of Archaean and Paleoproterozoic continental deformations (see Cagnard et al., 2006a; Chardon et al., 2009; Gapais et al., 2009). The model involves a weak converging continental crust whose buoyancy acts against subduction during shortening, thus favouring combined vertical thickening and lateral horizontal flow (Fig. 1c). 
(a)

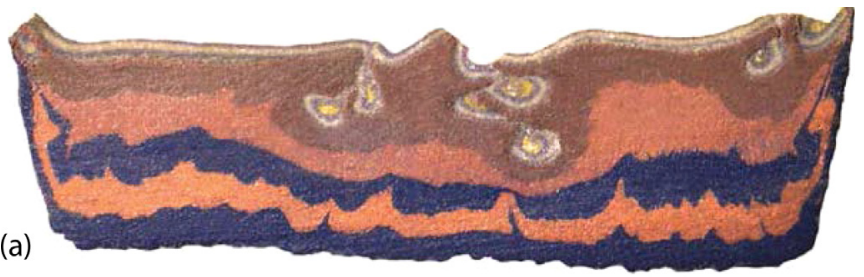

(b)
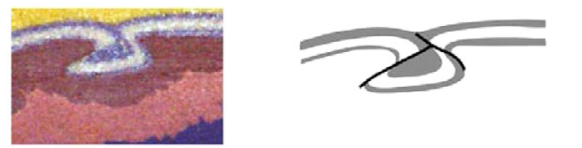

Pop-down
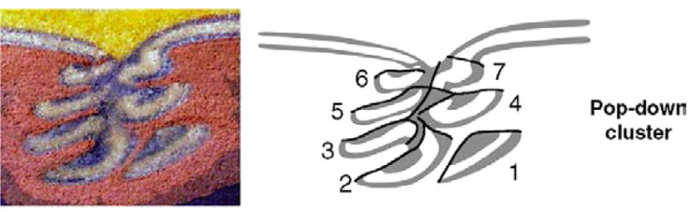

Fig. 6. Examples of results of analogue modelling of shortening of a weak continental lithosphere. (a) Cross-section through a model with $50 \%$ shortening showing localised piling-up of upper-crustal pop downs. (b) Evolution of pop down piling-up $(1,2,3,4 \ldots)$ during progressive deformation. Modified after Cagnard et al., 2006b.

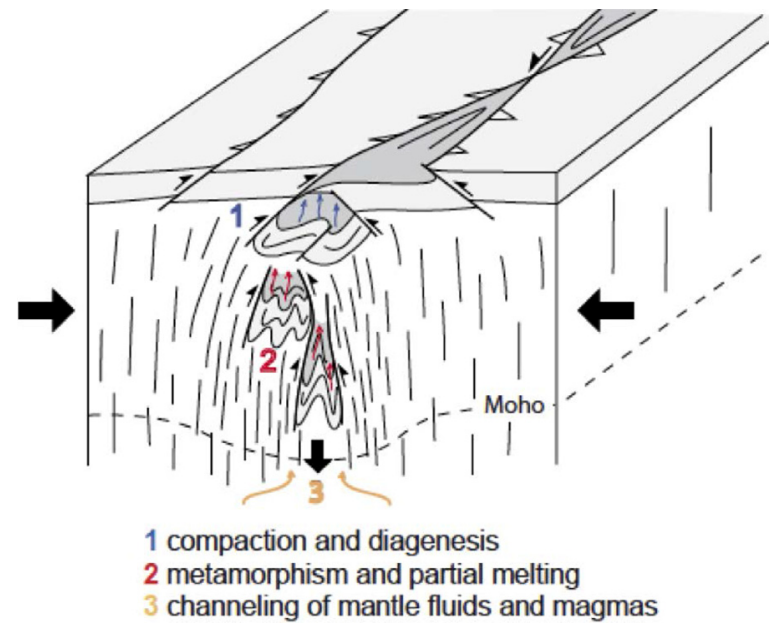

Fig. 8. Pop-down tectonic model underlying that progressive burial of supracrustals is expected to be accompanied by fluid release and transfer during their compaction, diagenesis, metamorphism, and partial melting. Magma production and interactions with the lithospheric mantle may also contribute to fluid-rock interactions. Modified after Gapais et al., 2014. See text for further explanations.
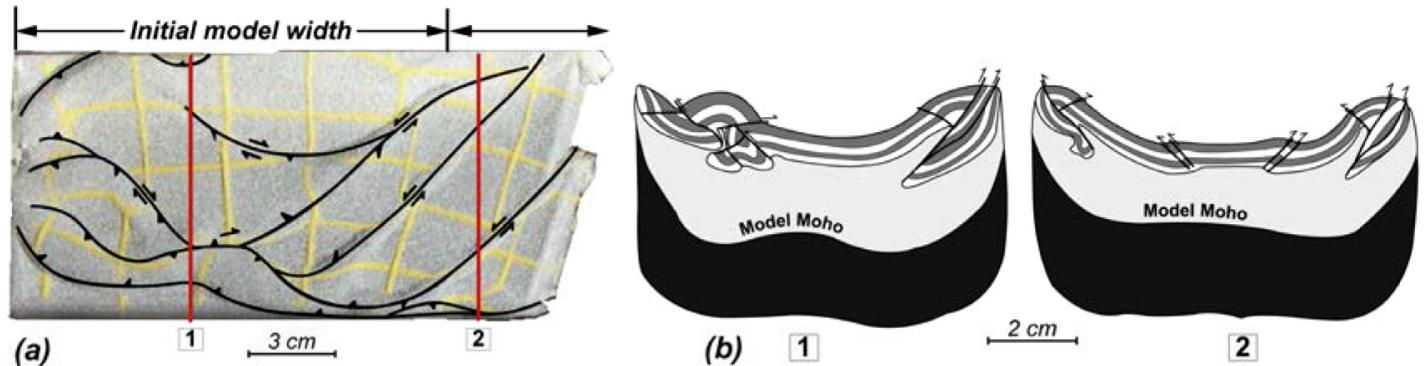

Fig. 7. Example of results of analogue modelling of shortening of a weak continental lithosphere with a free lateral boundary. (a) Surface view of a 50\% shortened model showing lateral extrusion accommodated by transfer shear zones. Block rotations between shear zones are underlined by initially orthogonal coloured markers drawn on model surface before deformation. (b) Cross-sections far from the extruded zone (1) and within it (2). These underline significant differences between ductile crust thickness far (doubled ductile crust) and within the extruded zone. Modified after Cagnard et al., 2006a.

\section{Deformation modes of weak lithospheres: what do analogue models tell us}

A series of analogue models was performed in the early 20th in order to examine the modes of deformation of weak lithospheres submitted to regional shortening (Cagnard et al., 2006a, b). These models followed the pioneer ones of Davy and Cobbold (1991).

Models developed by Cagnard et al. (2006b) involved a weak lithosphere made from top to bottom of (i) a rather thin upper brittle crust made of sand, (ii) a weak ductile lower crust made of silicone putty, and a ductile lithospheric mantle also made of silicone putty. The model lithosphere was floating on a dense model asthenosphere made of glycol and sodium polytungstate.
For ductile layers, viscosities were scaled between 1 and $2.2 \times 10^{4}$ Pas for the crust and between 3.4 and $4 \times 10^{4}$ Pas for the mantle. A normal density profile was fixed for all models, with 1.35 for the brittle crust, 1.42 for the ductile crust, 1.52 for the ductile mantle and 1.62 for the asthenosphere.

Main results are summarized in Figures 6 and 7, with the following main outcomes (details in Cagnard et al., 2006a, b):

- downward motions of thrust bounded pieces of upper crust that define pop-down structures that pile up along vertical deformation zones during progressive shortening. These vertical zones are high-strain zones with respect to surrounding domains;

- distributed shortening, marked by an overall flat-lying Moho and homogeneous thickening of ductile layers, 


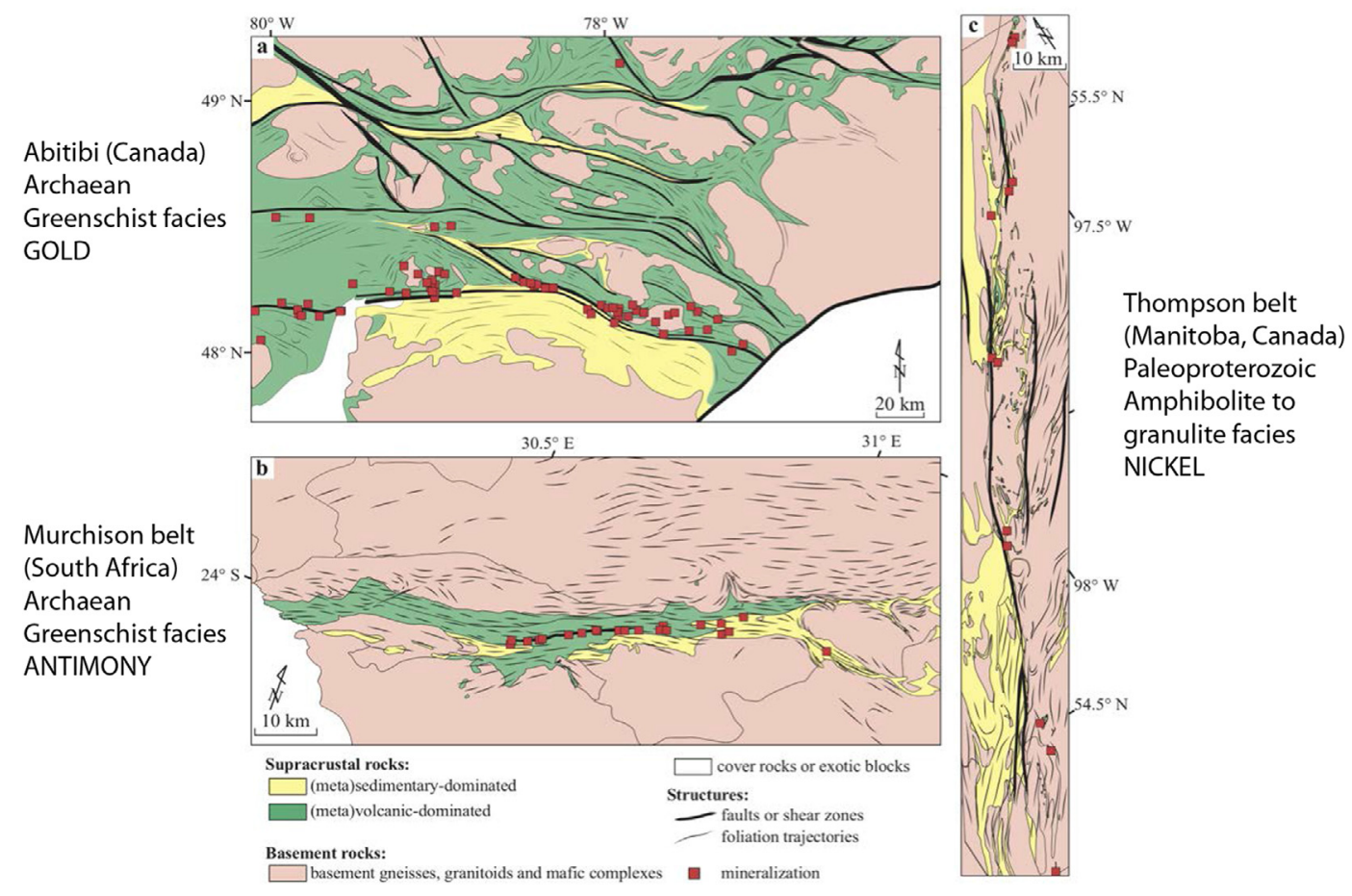

Fig. 9. Maps showing three typical examples of comparable geometric relationships between major steeply dipping deformation zones, occurrence of metamorphic supracrustals, and mineralisation. (a) Greenschist-facies Archaean gold-bearing southern Abitibi (Quebec), (b) Greenschist to lower amphibolite facies Archaean Antimony-bearing Murchison belt (South Africa). (c) High-grade amphibolite facies Paleoproterozoic Nickel-bearing Thompson Belt (Manitoba, Canada). Modified after Gapais et al., 2014. See text for further explanations.

except along particular zones of pop-downing and associated strain localisation;

- consistent lack of crustal or lithospheric thrusts, thrusts being limited to the brittle upper crust.

In experiments performed with a free lateral boundary, vertical strains are accompanied by along strike horizontal flow of the ductile crust (Fig. 7). Differential horizontal flow is principally accommodated by vertical zones of pop-downing that actually act as transfer zones with combinations of vertical and wrenching motions.

\section{Structure-mineralisation relationships}

\subsection{Potential fluid-rock interactions in pop-down models}

Analogue models and field examples summarized above emphasize that pop-down tectonics may be a convenient kinematic model to account for structural patterns often observed within shortened Archaean and Paleoproterozoic deformation belts. From this, Gapais et al. (2014) emphasized that zones of pop-down piling up might be exceptionally favourable for fluid transfers and fluid-rock interactions. First, these zones are subvertical crustal-scale deformation zones. Second, they may constitute localised channels for various fluids (Fig. 8). These include fluids released by burial of supracrustals successively submitted to diagenesis, metamorphism, and eventually partial melting and magma production. Furthermore, fluid interactions between crust and mantle may occur within crustal-scale vertical deformation zones. Thus, analogue models show that popping down of upper crustal rocks may reach the lower crust, and field examples, emphasize that, beside greenstones, magmatic bodies involving mantle components are observed within such vertical deformation zones (e.g., Thompson belt, Murchison belt, South Abitibi).

\subsection{Some field examples}

First order geological features linking mineralisation and structures within some Archaean and Paleoproterozoic belts are strong geometrical and lithological correlations. Mineralisation is actually mainly located within supracrustal units that mark out long-lasting vertical deformation zones. Examples from the Thompson Nickel Belt (Manitoba, Canada), the Murchison Belt (South Africa), and the southern Abitibi (Quebec, Canada) are shown on maps in Figure 9. These three examples are quite representative (Gapais et al., 2014). They indeed belong to different shortened deformation belts marked by different ages (Archaean and Paleoproterozoic), different metamorphic environments (from upper to low grade greenschist facies to partially melted middle crust), and different types of mineralisation (gold, antimony, nickel) (Gapais et al., 2014). In Southern Abitibi, gold occurrences are concentrated along transpressive shear zones and zones made of upper-crust volcanics and sediments, especially along the Cadillac fault zone (Fig. 9a). In the Murchison belt, Antimony Is located along the so called "Antimony Line", a sinistral transpressive shear zone within greenstones and metasediments (Fig. 9b). In the Thompson example, primary sources 


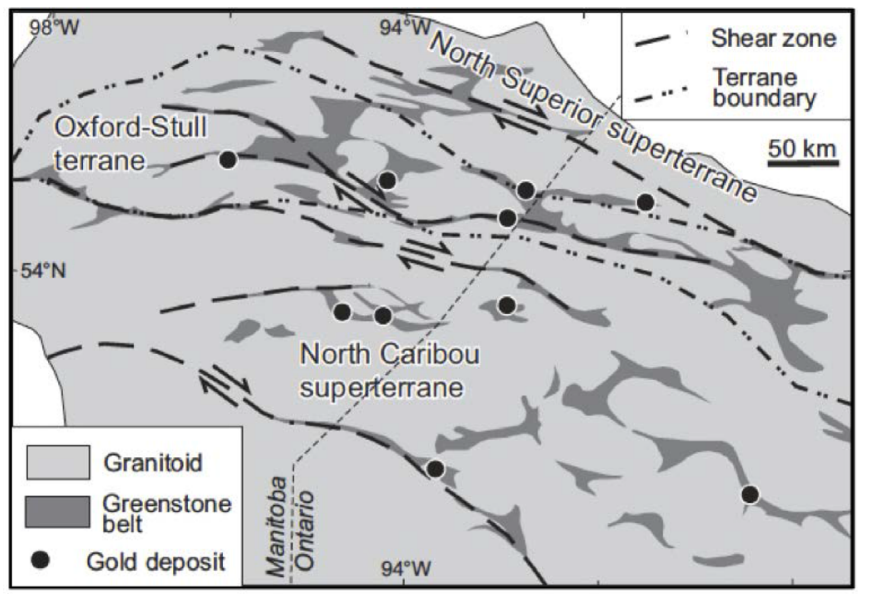

Fig. 10. Map showing geometric relationships between major transpressive zones, occurrences of supracrustals, and gold mineralisation in the Hemlo gold District from the Archaean Superior Province (Ontario, Canada). Modified after Lin and Beakhouse, 2013.

for nickel deposits are associated with mafic volcanics, sinks are within Paleoproterozoic sediments, both being connected via transpressive shear zones (Fig. 9c). Although these examples have different mineralisation histories, they show similar geometrical relationships between major vertical transpressive deformation zones marked by uppercrustals affected by large vertical strains and deep burial.

\subsection{Further potential applications}

\subsubsection{The Superior Province (Canada)}

The Archaean Superior Province consists of alternating elongate domains of upper-crust deposits (greenstones and sediments) and of underlying basement gneisses and granitoids. The region is a reference for models of vertical transpressive deformations involving sagduction and diaprism (see Lin and Beakhouse, 2013 and refs. therein).

Close geometrical relationships between mineralisations, steeply dipping shear zones marked by vertical motions of upper crust deposits were recently emphasized by Lin and Beakhouse (2013) in the Hemlo district, a gold rich area of the Archaean greenstone belt Superior Province (Ontario and Manitoba) (Fig. 10). These authors proposed an interpretation based on gravity driven sagduction, but our pop-down model may also be quite convenient to account for the field data that basically emphasize transpressive vertical tectonics.

\subsubsection{The Athabasca deformation belt (Canada)}

The Athabasca region (Saskatchewan, Canada) is the first uranium metallogenic province on the Earth. Mines, among which the world-wide known McArthur and Cigar Lake mines, are aligned along a major NE-SW striking mylonitic boundary between an Archaean domain to the west (the Mudjatik domain) and a Paleoproterozoic domain to the east (the Wollaston domain) (Fig. 11a). The mylonitic zone, well defined in terms of geological and geophysical signatures, is
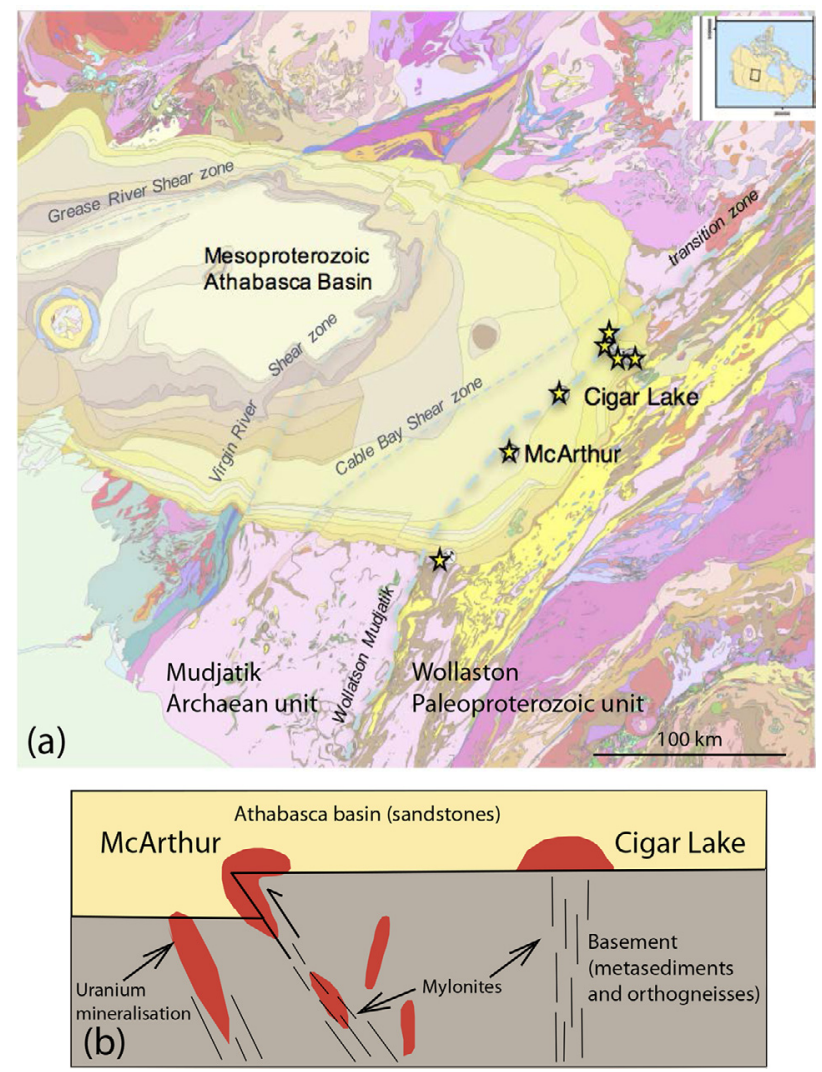

Fig. 11. General tectonic setting of the Athabasca Uranium deposits along the Wollaston-Mudjatik Zone (Saskatchewan, Canada). (a) Geological map showing location of mining areas along the Wollaston-Mudjatik zone and mainly below the Athabaska basin (After Annesley et al., 2005). (b) Schematic cross-section showing typical occurrences of uranium deposits along major basement major mylonitic shear zones and at basement-basin interface above them (Illustration from courtesy of AREVA).

known as the Wollaston-Mudjatik transition zone. Most mines along this zone are located at the base of the Athabasca basin made of Paleoproterozoic to early Mesoproterozoic detrital sediments, or within the underlying basement (Fig. 11b). A remarkable feature is that uranium-rich zones are closely associated with steeply dipping mylonitic zones that affect the basement below the basin (Fig. 11b). The updated metallogenic models for the generation of these deposits invoke the precipitation of Uranium-enriched fluids in structural-chemical traps, along steep reactivated basement deformation zones (Jefferson et al., 2007; Li et al., 2017). Indeed, these zones show evidence of late compressive reactivation (Fig. 11b), providing channels for the circulation of reduced fluids originated from the basement and of oxydized fluids from the basin, as well as good traps for the formation of high-grade uranium deposits (Fig. 12a). In the field, the WollastonMudjatik zone is marked by (i) a subvertical mylonitic foliation bearing a steeply plunging stretching lineation (Fig. 12b), (ii) Paleoproterozoic metasediments (Fig. 12b) locally partially melted, and (iii) widespread magmatic intrusions including crust and mantle derived ones (Annesley 

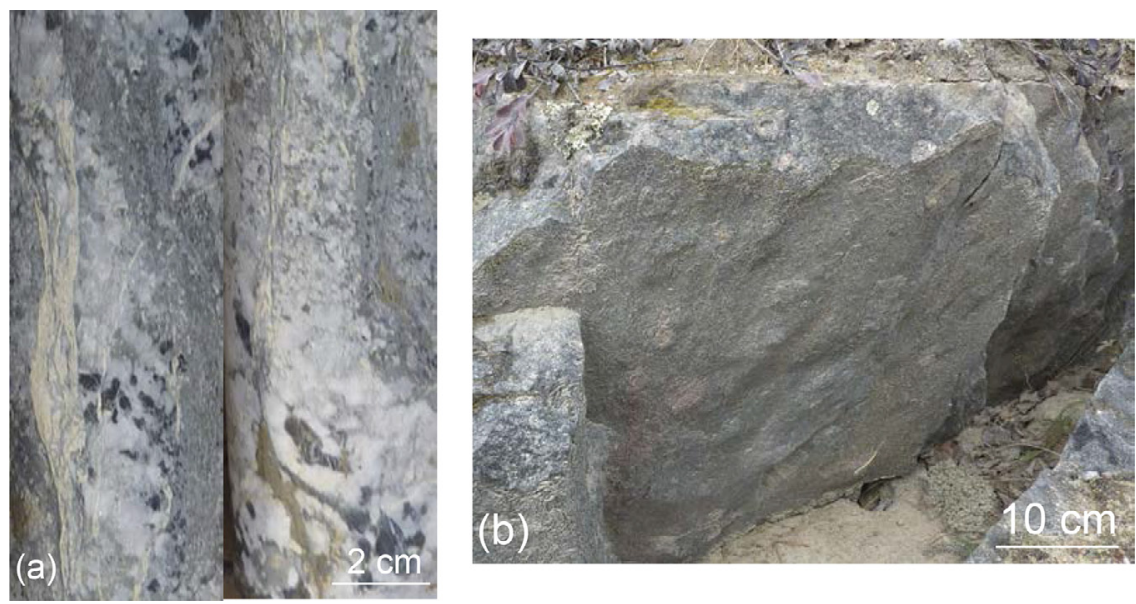

Fig. 12. Photographs showing structures within mylonitic zones associated with uranium deposits in the Wollaston-Mudjatik Zone (eastern Athabaska area). (a) Steep mylonitic foliation with high-grade metasediments reworked by steeply dipping mineralised faults (carbonatesulfides bearing mineralisation). (b) Field aspect of the regional fabric marked by steeply dipping foliations bearing substantially plunging stretching lineations (here in a Paleoproterozoic meta-conglomerate).

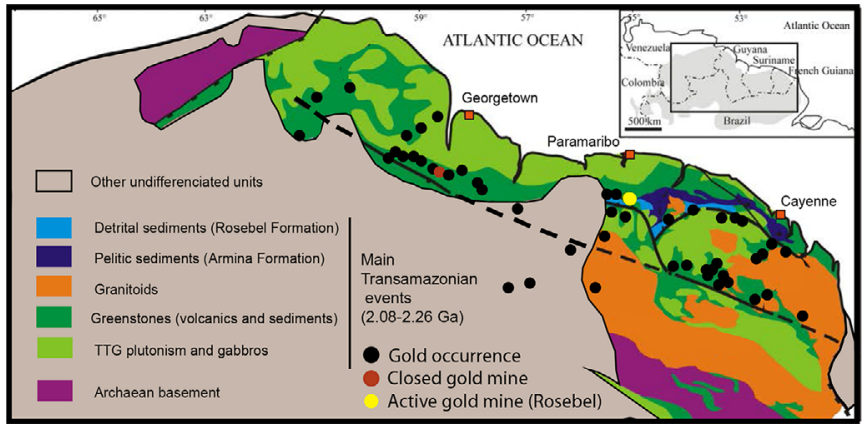

Fig. 13. Simplified geological map of the gold-bearing TransAmazonian Paleoproterozoic belt. The map underlines close relationships between supracrustal greenstones and sediments and gold occurrences. Modified after Delor et al., 2003.

et al., 2005). The Wollaston-Mudjatik zone has a complex and long-lasting deformation history (Annesley et al., 2005), but points to important vertical motions involving deep burial of supracrustals and to substantial crust-mantle connections and associated magmatism, features that strongly suggest popdown type tectonic processes.

\subsubsection{The Transamazonian belt}

The Transamazonian deformation belt extends along the northeastern coast of South America, in the Guyana-Suriname area (Fig. 13). It is marked by widespread gold occurrences spread along Paleoproterozoic greenstones and sedimentary units (Fig. 13). In the Rosebel area, the major gold district of Suriname, gold occurs in quartz-carbonate veins within Paleoproterozoic detrital sediments, mainly conglomerates, sandstones, siltstones, and greywakes. Structures of the Rosebel district emphasize that deformations involved substantial vertical stretching along subvertical pervasive cleavages (Fig.3a) that affect major deformation zones localised within supracrustals and associated with sets of steeply dipping conjugate transpressive shear zones (Daoust
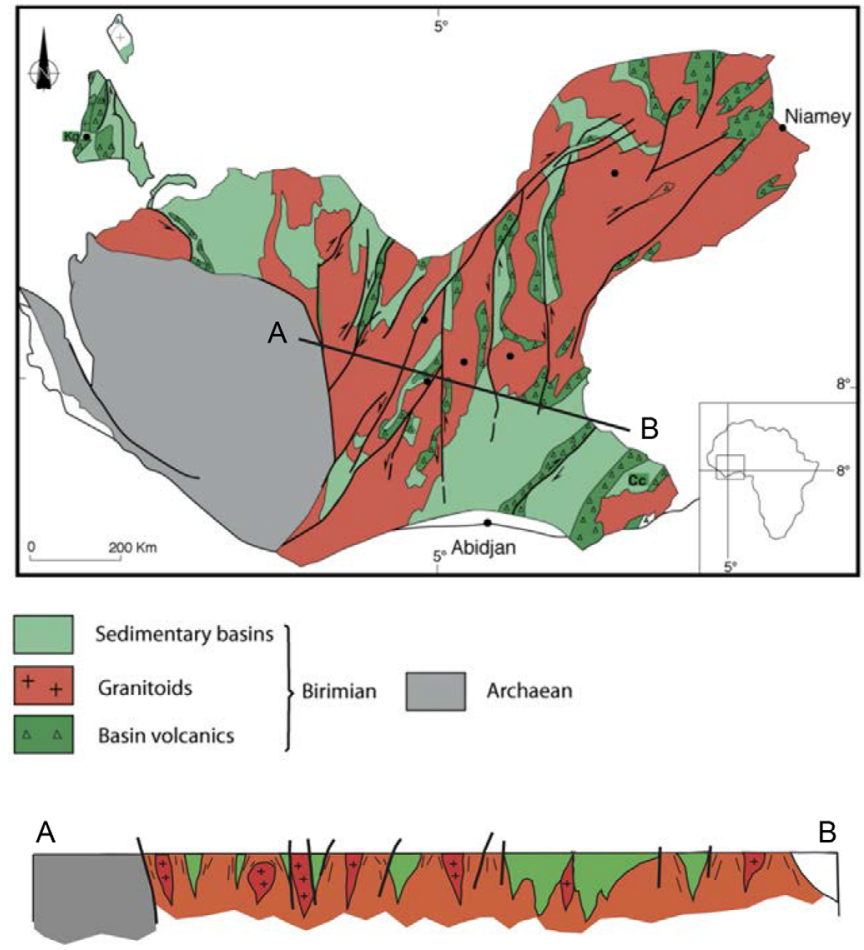

Fig. 14. Geological map (a) and cross-section (b) of the Birimian domain of western Africa. Modified after Lompo, 2010. See text for further explanations.

et al., 2011; Daoust, 2016; Alimoenadi et al., submitted). These features that show localised vertical deformations within supracrustal units strongly support pop-down deformation modes (Alimoenadi et al., submitted).

\subsubsection{The Birimian domain of western Africa}

The Birimian Paleoproterozoic of western Africa was linked to the Transamazonian belt before the opening of the 


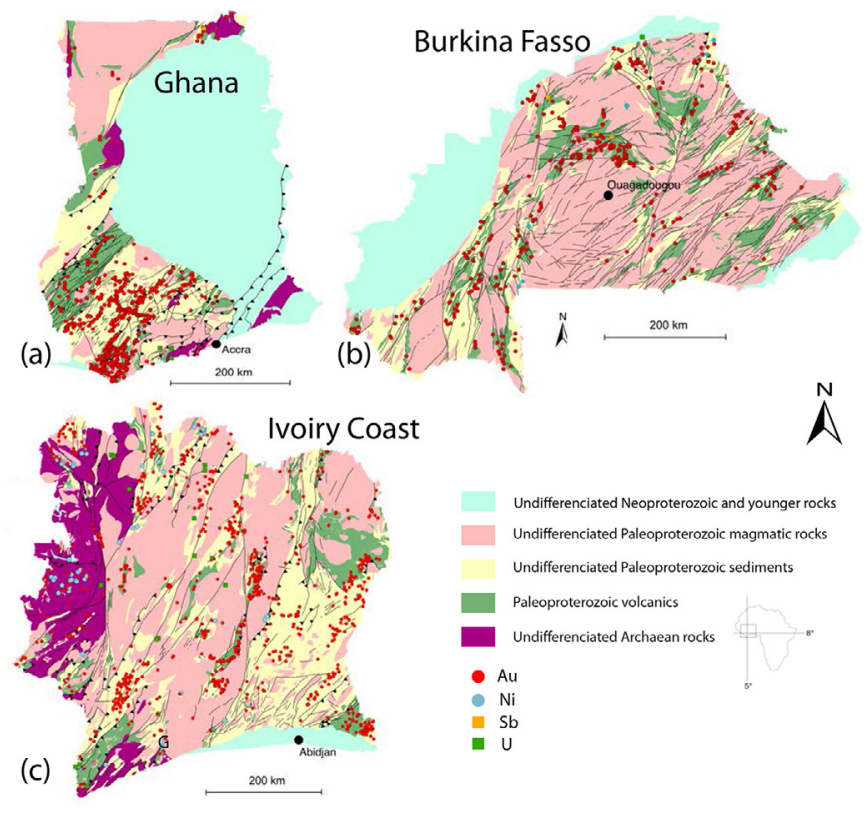

Fig. 15. Maps of the Birimian of western Africa showing geometrical relationships between main deformation zones, supracrustals, and ore indexes. (a) Ghana. (b) Burkina-Fasso. (c) Ivoiry Coast. Data from courtesy of the BRGM.

Atlantic Ocean. It consists of NNE-SSW trending alternating domes of granitic rocks and of basins filled by detrital sediments and volcanics (Fig. 14a and b). The overall structure marked by vertical anastomosed deformation zones associated with dome and basin geometries attests to vertical motions (Lompo, 2010).

In the region, close map-scale relationships between domains of sediments and volcanics, major steeply dipping deformation zones, and mineralisation are observed (Fig. 15).

\section{Boundary conditions and displacement- strain relationships}

Boundary conditions are of course quite difficult to appraise in ancient deformation zones. Furthermore, kinematic indicators are there generally poorly expressed compared with what can be observed along major crustal-scale shear zones such as wrench zones, thrusts or extensional detachments that are typical of modern orogenic belts. From the above examples, the widespread steeply plunging principal stretch along steeply dipping fabrics (Figs. 3 and $4 a, b$ ) is basically consistent with dominant vertical motions and with the observed burial of supracrustal sediments at HT conditions with often partial melting (Chardon et al., 2009; Gapais et al., $2009,2014)$. These geometries imply steeply dipping ductile shear zones that accompany downward motion of uppercrustal rocks, as produced in analogue models.

On the other hand, most field examples attest to transpressive motions involving wrenching components along the steeply dipping deformation zones (Fig. 1c) (see Chown et al., 1992; Daigneault et al., 2002; Annesley et al., 2005; Gapais et al., 2005, 2009; Chardon et al., 2009; Lompo, 2010; Daoust et al., 2011; Jaguin et al., 2012; Lin and Beakhouse, 2013). According to theoretical models, combinations of strike-slip and vertical motions should result in flattening strains and vertical stretch (see Dewey et al., 1997; Merle and Gapais, 1997). Nevertheless, a steeply plunging attitude of the principal stretch direction is not sufficient to precisely estimate ratios between vertical and horizontal motions, because a large range of ratios between strike-slip and pure shear components results in vertical infinitesimal principal stretching (Dewey et al., 1997).

Detailed kinematic analysis of deformation features along main deformation zones often reveal complex kinematic histories with different successive structure development, locally puzzling and apparently incompatible with a simple progressive deformation history (e.g., Chown et al., 1992; Daigneault et al., 2002; Annesley et al., 2005; Lompo, 2010; Daoust, 2016; Kroonenberg et al., 2016).

There may be several reasons that may contribute to this. A first one is that main deformation zones are often major "terrain" boundaries, favourable for reactivation, long-lasting and (or) superposed deformations, and attached potential changes in kinematics. On the other hand, results of analogue modelling summarized here have underlined the potential role of transfer shear zones that develop between different crustal blocks submitted to differential lateral extrusion during compression and burial of uppercrustals (Fig. 7). Kinematic questions linked to combinations of vertical motions and lateral ones, and modes of reactivation of major tectonic boundaries are attached to each particular field example and would require further specific investigations out of the scoop of the present paper.

\section{Concluding remarks}

From the summary of structural analyses of several deformation zones within Archaean and Paleoproterozoic domains and their comparison with analogue modelling of compression of weak continental lithospheres, one may underline the following features:

- compression modes of ancient weak lithospheres may strongly differ from those observed in modern ones. They mainly accommodate shortening by distributed vertical stretching and crustal thickening;

- the present-day most suitable model that may account for the deformation patterns in many ancient tectonic zones is pop-down tectonics that involves vertical burial of supracrustals during continental convergence. This is outlined by both analogue models and field examples;

- the geometrical relationships between mineralisation of various types and structural patterns involving burial of supracrustals along vertical deformation zones appear shared by many deformation belts of Archaean and Paleoproterozoic age.

From these, we propose that pop-down tectonics should be considered as a most promising tectonic framework for ore prospection in ancient cratons.

Acknowledgments. This paper summarises several works published by several researchers and co-authors since the middle 2000th. Thanks to them. Figure 2 was drawn from data provided by the Canadian Natural Resources (2015). Further thanks to AREVA and IAMGOLD companies for allowing me 
to publish new data from their mining areas. Comments by two anonymous reviewers have contributed to substantial improvements of the initial manuscript.

\section{References}

Alimoenadi G, Gapais D, Balraadjsing N, Poupeau B. The Rosebel gold mining district (Transamazonian belt, Suriname), a new structural framework. Precamb Res, submitted.

Annesley IR, Madore C, Portella P. 2005. Geology and thermotectonic evolution of the western margin of the Trans-Hudson Orogen: evidence from the eastern sub-Athabasca basement, Saskatchewan. Can J Earth Sci 42: 573-597. Doi: 10.1139/E05-034.

Bédard JH. 2018. Stagnant lids and mantle overturns: Implications for Archaean tectonics, magmagenesis, crustal growth, mantle evolution, and the start of plate tectonics. Geoscience Frontiers 9: 19-49.

Block S, Moyen JF, Zeh A, Poujol M, Jaguin J, Paquette JL. 2013. The Murchison Greenstone Belt, South Africa: Accreted slivers with contrasting metamorphic conditions. Precambrian Research 227: 77-98. Doi: 10.1016/j.precamres.2012.03.005.

Block S, Ganne L, Baratoux L, Zeh L, Parra-Avila M. Jessel, et al. 2015. Petrological and geochronological constraints on lower crust exhumation during Paleoproterozoic (Eburnean) orogeny, NW Ghana, West African Craton. J Metamorph Geol 33: 463-494.

Brun JP, Gapais D, Le Théoff B. 1981. The Mantle Gneiss Domes of Kuopio (Finland): interfering diapirs. Tectonophysics 74: 283-304.

Cagnard F, Durrieu N, Gapais D, Brun JP, Ehlers C. 2006 a. Convergence tectonics within weak lithospheres: a working hypothesis with particular reference to Precambrian times. Terra Nova 18: 72-78.

Cagnard F, Brun JP, Gapais D. 2006b. Modes of thickening of weak lithospheres: insights from analogue experiments. Tectonophysics 421: 145-160.

Cagnard F, Gapais D, Barbey P. 2007. Collision tectonics involving juvenile crust: example of the southern Svecofenides. Precamb Res 154: 125-141.

Chardon D, Choukroune P, Jayananda M. 1998. Sinking of the Dharwar Basin (South India): implications for Archaean tectonics. Precamb Res 91: 15-39.

Chardon D, Gapais D, Cagnard F. 2009. Flow of ultra-hot orogens: a view from the Precambrian, clues for the Phanerozoic. Tectonophysics 477: 105-118.

Choukroune P, Bouhallier H, Arndt NT. 1995. Soft lithosphere during periods of Archean crustal growth or crustal reworking. In: Coward MP, Ries AC, eds. Early Precambrian Processes. Geol Soc Spec Publ 95: 67-86.

Chown EH, Daigneault R, Mueller W, Mortensen JK. 1992. Tectonic evolution of the Northern Volcanic Zone, Abitibi belt, Quebec. Can J Earth Sci 29: 2211-2225.

Collins WJ, Van Kranendonk MJ. 1998. Partial convective overturn of Archaean crust in the east Pilbara Craton, western Australia: driving mechanisms and tectonic implications. J Struct Geol 20: 1405-1424.

Daigneault R, Mueller WU, Chown EH. 2002. Oblique Archaean subduction: accretion and exhumation of an oceanic arc during dextral transpression, Southern Volcanic Zone, Abitibi Subprovince Canada. Precamb Res 115: 261-290.

Daoust C. 2016. Caractérisation stratigraphique, structurale et géochimique du district minéralisé de Rosebel (Suriname) dans le cadre de l'évolution géodynamique du bouclier guyanais. $\mathrm{PhD}$. Thesis, UQAM, $353 \mathrm{p}$.
Daoust C, Voicu G, Brisson H, Gauthier M. 2011. Geological setting of the Paleoproterozoic Rosebel gold district, Guiana Shield, Suriname. J South Am Earth Sci 32: 222-245.

Davy P, Cobbold PR. 1991. Experiments on shortening of a 4-layer model of the continental lithosphere. Tectonophysics 188: 1-25.

Delor C, Lahondère D, Egal E, Lafon J-M., Cocherie A, Guerrot C, et al. 2003. Transamazonian crustal growth and reworking as revealed by the 1:500 000 scale geological map of French Guiana. Géologie de la France 2-3-4: 5-57.

De Sigoyer J, Chavagnac V, Blichert-Toft J, Villa IM, Luais B, Guillot $\mathrm{S}$, et al. 2000. Dating the Indian continental subduction and collisional thickening in the northwest Himalaya: multichronology of the Tso Morari eclogites. Geology 28: 487-490.

De Sigoyer J, Guillot S, Dick P. 2004. Exhumation of the ultrahighpressure Tso Morari unit in the eastern Ladakh (NW Himalaya): a case study. Tectonics 23: TC 3000. DOI: 10.1029/20002TC001492.

Dewey JF, Bird JM. 1970. "Mountain belts and new global tectonics". $J$ Geophys Res 75(14): 2625-2685.

Dewey JF, Holdsworth RE, Strachan RA. 1997. Transpression and transtension zones. In: Holdworth RE, Strachan RA, Dewey JF, eds. Continental transpressional and transtensional tectonics. Geol Soc London Spec Pub 135: 1-14.

Dixon JM. 1975. Finite strain and progressive deformation in models of diapiric structures. Tectonophysics 28: 89-124.

Eskola PE. 1949. The problem of mantled gneiss domes. Q J Geol Soc London 104: 461-476.

Gapais D, Gilbert E, Pêcher A. 1992. Synconvergence spreading of the Higher Himalaya Crystalline. Tectonics 11: 1045-1056.

Gapais D, Potrel A, Machado N, Hallot E. 2005. Kinematics of longlasting Paleoproterozoic transpression within the Thompson Nickel Belt (Manitoba, Canada). Tectonics 24: 1-16.

Gapais D, Pelletier A, Ménot RP, Peucat JJ. 2008. Paleoproterozoic tectonics in the Terre Adélie Craton (East Antarctica). Precamb Res 162: 531-539.

Gapais D, Cagnard F, Gueydan F, Barbey P, Ballèvre M. 2009. Mountain building and exhumation processes through time: inferences from nature and models. Terra Nova 21: 188-194.

Gapais D, Jaguin J, Cagnard F, Boulvais P. 2014. Pop-down tectonics, fluid channelling and ore deposits within ancient hot orogens. Tectonophysics 618: 102-106.

Goodfellow WD. 2007. Mineral deposits of Canada: a synthesis of major deposit-types, district metallogeny, the evolution of geological provinces, and exploration methods. Geological Association of Canada, Mineral Deposits Division, Special Publication no. 5, 1061 p. 4 dvds (ESS Cont. $\neq 20070187)$.

Jaguin J, Gapais D, Poujol M, Boulvais P, Moyen JF. 2012. Tectonics of the Murchison Greenstone Belt (South Africa): a general Framework. South African J Geol 115.1: 63-74. Doi: 10.2113/ gssajg.115.1.74.

Jefferson CW, Thomas DJ, Gandhi SS, Ramaekers P, Delaney G, Brisbin D, et al. 2007. Unconformity-associated uranium deposits of the Athabasca Basin, Saskatchewan and Alberta. In: Goodfellow W, ed. Mineral Deposits of Canada: Geological Association of Canada. Mineral Deposits Division, Special Publication 5: 273305.

Korsman K, Koistinen T, Kohonen J, Wennerström M, Ekdahl E, Honkamo, et al. (Eds.). 1997. Bedrock Map of Finland 1:1 000 000: Geological Survey of Finland. Espoo.

Kroonenberg SB, de Roever EWF, Fraga LM, Reis NJ, Faraco T, Lafon J-M, et al. 2016. Paleoproterozoic evolution of the Guiana Shield in Suriname: A revised model. Netherlands Journal of Geosciences: 1-32. DOI: 10.1017/njg.2016.10.

Le Pichon X. 1968. Sea-floor spreading and continental drift. $J$ Geophys Res 73(12): 3661-3697. 
Li Z, Chi X, Bethune KM, Eldursi K, Thomas D, Quirt D, et al. 2017. Synchronous egress and ingress fluid flow related to compressional reactivation of basement faults: the Phoenix and Gryphon uranium deposits, southeastern Athabasca Basin, Saskatchewan, Canada. Mineralium Deposita. Doi: 10.1007/ s00126-017-0737-5.

Lin S, Beakhouse GP. 2013. Synchronous vertical and horizontal tectonism at late stages of Archaean cratonization and genesis of Hemlo gold deposits, Superior craton, Ontario, Canada. Geology 41: 359-362.

Lompo M. 2010. Paleoproterozic structural evolution of the ManLao-Shield (West Africa). Key structures for vertical to transcurrent tectonics. J African Geol 58: 19-36.

McKenzie D, Parker RL. 1967. The north pacific: An example of tectonics on a sphere. Nature 216: 1276-1280.

Merle O, Gapais D. 1997. Strain within thrust-wrench zones. J Struct Geol 19 (7): 1011-1014.

Morgan WJ. 1968. Rises, Trenches, great faults, and crustal blocks. $J$ Geophys Res 73(6): 1959-1982.

Nelson KD, Zhao W, Brown LD, Kuo J, Che J, Liu X, et al. 1996. Partially molten middle crust beneath Southern Tibet: Synthesis of Project INDEPTH Results. Science 274: 1684-1689.

Pelletier A, Guiraud M, Ménot RP. 2005. From partial melting to retrogression in the Pointe Géologie migmatitic complex: a history of heterogeneous distribution of fluids. Lithos 81: 153-166.

Peucat JJ, Ménot RP, Monnier O, Fanning MC, 1999. The Terre Adélie basement in the East-Antarctica Shield: geological and isotopic evidence for a major $1.7 \mathrm{Ga}$ thermal event; comparison with the Gawler Craton in south Australia. Precamb Res 94: 205-224.
Précigout J, Gueydan F, Gapais D, Garrido CJ, Essaifi A. 2007. Strain localisation in the sub-continental mantle-a ductile alternative to the brittle mantle. Tectonophysics 445: 318-336.

Ramberg H. 1963. Experimental study of gravity tectonics by means of centrifuged models. Bull Inst Univ Uppsala 42: 1-97.

Ramberg H. 1967. Gravity, Deformation and the Earth's Crust. London: Academic Press, 214 p.

Ranalli G. 1997. Rheology of the lithosphere in space and time. In: Burg JP, Ford M, eds. Orogeny through time. Geol Soc London Spec Pub 121: 19-37.

Rey P, Houseman G. 2006. Lithospheric scale gravitational flow: the impact of body forces on orogenic processes from Archaean to Phanerozoic. In: Butler SJH, Schreurs G, eds. Analogue and numerical modelling of crustal-Scale processes. Geol Soc London Spec Pub 253: 153-167.

Sandiford M, McLaren S. 2002. Tectonic feedback and the ordering of heat producing elements within the continental lithosphere. Earth Planet Sci Lett 204: 133-150.

Schwerdtner WM, Stone D, Osadetz K, Morgan J, Stott GT. 1979. Granitoid complexes and the Archaean tectonic record in the southern part of northwestern Ontario. Can J Earth Sci 16: 1965-1977.

Väisänen M, Hölltä P. 1999. Structural and metamorphic evolution of the Turku migmatite complex, Southwestern Finland. Bull Geol Soc Fin 71: 177-218.

Windley BF. 1992. Proterozoic collisional and accretionary orogens. In: Condie KC, ed. Paleproterozoic Crustal Evolution. Amsterdam: Elsevier, pp. 419-446.

Windley BF. 1995. The evolving continents. Chichester: J. Wiley \& Sons, $526 \mathrm{p}$.

Cite this article as: Gapais D. 2018. Tectonics-mineralisation relationships within weak continental lithospheres: a new structural framework for Precambrian cratons, BSGF - Earth Sciences Bulletin 189: 14. 